\title{
Trauma recidivism in a Canadian province: a 14-year registry review
}

\author{
Mete Erdogan, $\mathrm{PhD}, \mathrm{MHI}^{*} \|$; Nelofar Kureshi, MBBS, $\mathrm{MHI}^{\dagger} \|$; Mark Asbridge, $\mathrm{PhD}, \mathrm{MA}^{\ddagger}$; \\ Robert S. Green, MD§
}

\section{CLINICIAN'S CAPSULE}

What is known about the topic?

Trauma recidivism rates range from $1 \%$ to $44 \%$, yet the rate of major trauma recidivism is unknown at a provincial level.

What did this study ask?

What is the rate of major trauma recidivism in Nova Scotia, and what factors are associated with recidivism and mortality?

What did this study find?

Major trauma recidivism was infrequent; however, the adjusted odds of mortality were over three times greater for recidivists.

Why does this study matter to clinicians?

Screening and brief intervention in cases of major trauma involving violence or substance abuse may help reduce rates of recidivism.

\section{ABSTRACT}

Objectives: To determine the rate of recurrent major trauma (i.e., trauma recidivism) using a provincial population-based trauma registry. We compared outcomes between recidivists and non-recidivists, and assessed factors associated with recidivism and mortality.

Methods: Review of all adult ( $>17$ years) major trauma patients in Nova Scotia (2001-2015) using data from the Nova Scotia Trauma Registry. Outcomes of interest were mortality, duration of hospital stay, and in-hospital complications. Multiple regression was used to assess factors associated with recidivism and mortality.

Results: Of 9,365 major trauma patients, $2 \%$ (150/9365) were recidivists. Mean age at initial injury was $52 \pm 21.5$ years; $73 \%$ were male. The mortality rate for both recidivists and non-recidivists was $31 \%$. However, after adjusting for potential confounders the likelihood of mortality was over 3 times greater for recidivists compared to non-recidivists (OR 3.67, 95\% Cl 2.066.54). Other factors associated with mortality included age, male gender, penetrating injury, Injury Severity Score, trauma team activation (TTA) and admission to the intensive care unit. The only variables associated with recidivism were age (OR $0.98,95 \% \mathrm{Cl} 0.97-1.00$ ) and TTA (OR 0.59, 95\% Cl 0.34-0.96).

Conclusions: This is the first provincial investigation of major trauma recidivism in Canada. While recidivism was infrequent $(2 \%)$, the adjusted odds of mortality were over three times greater for recidivists. Further research is warranted to determine the effectiveness of strategies for reducing rates of major trauma recidivism such as screening and brief intervention in cases of violence or substance abuse.

\section{RÉSUMÉ}

Objectif: L'étude visait à déterminer le taux de répétition (ou de récidive) de traumas graves à l'aide d'un registre provincial de traumas, fondé sur la population. Ont d'abord été comparés les résultats cliniques chez les " récidivistes " et les " non-récidivistes ", puis évalués les facteurs associés aux répétitions et à la mortalité.

Méthode: L'étude consistait en un examen des dossiers de tous les adultes (> 17 ans) ayant subi un trauma grave en Nouvelle-Écosse (2001-2015), à l'aide de données tirées du registre Nova Scotia Trauma Registry. Les résultats cliniques d'intérêt étaient la mortalité, la durée de séjour à l'hôpital et les complications survenues à l'hôpital. Par ailleurs, il y a eu régression multiple afin d'évaluer les facteurs associés aux répétitions et à la mortalité.

Résultats: Sur 9365 patients ayant subi un trauma grave, 150 (2\%) étaient des récidivistes. L'âge moyen au moment du premier accident était de $52 \pm 21,5$ ans, et $73 \%$ des patients étaient des hommes. Le taux de mortalité dans les deux groupes s'élevait à $31 \%$. Toutefois, après rajustement du taux pour tenir compte de possibles facteurs parasites, les probabilités de mort étaient 3 fois plus élevées chez les récidivistes que chez les non-récidivistes (risque relatif approché [RRA] : 3,67; IC à

From *Trauma Nova Scotia, Department of Health and Wellness, Halifax, NS; tDivision of Neurosurgery, Department of Surgery, Dalhousie University, Halifax, NS; ‡Departments of Community Health and Epidemiology and Emergency Medicine, Dalhousie University, Halifax, NS; §Department of Critical Care, Dalhousie University, Halifax, NS, Canada, B3H 4R2; and the ॥These authors contributed equally to the work.

Correspondence to: Dr. Robert S. Green, Room 1-026B Centennial Building, 1276 South Park Street, Halifax, NS, B3H 2Y9; Email: greenrs@ dal.ca 
$95 \%$ : 2,6-6,54). D'autres facteurs associés à la mortalité comprenaient l'âge, le sexe masculin, les blessures par pénétration, le score selon l'indice de gravité des blessures, l'appel à l'équipe de soins en traumatologie (EST) et l'admission au service de soins intensifs. Toutefois, seules deux variables ont été associées aux répétitions de traumas, soit I'âge (RRA : 0,98; IC à 95\% : 0,971,00 ) et l'appel à I'EST (RRA : 0,59; IC à 95\% : 0,34-0,96).

Conclusion: Il s'agit là de la première étude sur les répétitions de traumas graves, menée à l'échelle provinciale, au Canada. Si le taux de répétition était faible $(2 \%)$, les probabilités rajustées de mort chez les récidivistes étaient plus de 3 fois supérieures à celles enregistrées chez les non-récidivistes. II faudrait donc approfondir le sujet afin de déterminer l'efficacité des stratégies de réduction du taux de répétition de traumas graves, telles que le dépistage et les interventions brèves dans les cas de violence ou d'un usage abusif d'alcool ou de drogues.

Keywords: mortality, recidivism, trauma

\section{INTRODUCTION}

Major trauma recidivists are patients with a prior severe traumatic injury. ${ }^{1}$ Previous investigations of recidivism observed rates from $1 \%-2 \%{ }^{2,3}$ to $44 \%{ }^{4}$ In the only other Canadian study on recidivism to date, Caufeild and colleagues found an overall rate of $0.38 \%$ at two trauma centres in Toronto. ${ }^{5}$

Recidivists have higher long-term mortality after discharge ${ }^{6}$ and the mortality risk increases with each successive admission. ${ }^{7}$ Surprisingly, some have observed better hospital outcomes among recidivists. ${ }^{8}$ Recidivism is associated with a younger age, male gender, a penetrating injury, violence, and substance abuse. ${ }^{2,5,6}$ Our objective was to determine the major trauma recidivism rate in Nova Scotia. We compared outcomes between recidivists and non-recidivists and assessed for factors associated with recidivism and mortality.

\section{METHODS}

We reviewed all adult patients ( $>17$ years) who sustained a major trauma using data from the Nova Scotia Trauma Registry, a provincial population-based trauma registry under the Nova Scotia Department of Health and Wellness. The criteria for registry inclusion were: an Injury Severity Score of $\geq 12$, an appropriate International Classification of Diseases (ICD) External Cause of Injury Code, penetrating injuries with an Injury Severity Score of $\geq 9$, all trauma team activations, and deaths (at the scene, in the emergency department, and within 24 hours of admission). The staff of Trauma Nova Scotia identified patients meeting the registry inclusion criteria by reviewing records at all regional hospitals and tertiary care centres. Scene and pre-hospital deaths were identified by reviewing records from the Nova Scotia Medical Examiner Service. Trauma Nova Scotia considers a blood alcohol concentration of $\geq 2 \mathrm{mmol} / \mathrm{L}$ to be positive, as defined in the National Trauma Registry (NTR) data dictionary.

Major traumas between April 1, 2001, and March 31, 2015, were eligible. Individuals with more than one major trauma during the study period were considered recidivists. The primary outcome was the recidivism rate. Secondary outcomes were the length of stay (inhospital, intensive care unit (ICU), and intermediate care unit), the occurrence of complications (any ICD10-CA or NTR complication arising after hospital observation and influencing patient management or treatment), and mortality (including the scene, pre-hospital, and in-hospital deaths). Recidivists and non-recidivists were compared using Student's $t$-tests and a chi square analysis. We created two multivariate logistic regression models to assess for factors associated with recidivism and mortality. For recidivists, variables were based on their most recent injury. All variables were entered in a single step as a block. Adjusted odd ratios (ORs) are reported for measurement of the effect size with $95 \%$ confidence intervals (CIs). All analyses were performed using IBM SPSS Statistics (version 23; IBM Corp; Armonk, NY). ${ }^{9}$ Ethical approval was obtained from the Nova Scotia Health Authority Research Ethics Board.

\section{RESULTS}

Of 9,635 adult patients who sustained a major trauma, the recidivism rate was $2 \%(150 / 9635)$. Six patients had more than two traumas; no patient had more than four traumas. The mean duration between the initial and second injury was $41 \pm 40$ months (range $1-159$ months). Patient characteristics and outcomes are shown in Table 1. Recidivists 


\begin{tabular}{|c|c|c|c|c|c|}
\hline \multirow[b]{2}{*}{ Variable* } & \multirow{2}{*}{$\begin{array}{c}\text { Non-recidivists } \\
\quad(n=9485)\end{array}$} & \multicolumn{4}{|c|}{ Recidivists $(n=150)$} \\
\hline & & Initial injury & $p^{\dagger}$ & Recurrent injury & $p^{\dagger}$ \\
\hline \multicolumn{6}{|l|}{ Characteristics } \\
\hline No. of patients - overall, $n$ & 9485 & 150 & - & 150 & - \\
\hline Age, mean \pm SD & $52 \pm 21$ & $49 \pm 22$ & 0.20 & $53 \pm 22$ & 0.34 \\
\hline Male gender, $n(\%)$ & $6915(73)$ & $124(83)$ & 0.008 & $124(83)$ & 0.007 \\
\hline Blunt injury, $n(\%)$ & 7918 (83) & $129(86)$ & 0.41 & $123(82)$ & 0.62 \\
\hline ISS on arrival, mean \pm SD & $22 \pm 15$ & $18 \pm 8$ & 0.001 & $19 \pm 12$ & 0.018 \\
\hline TTA, $n(\%)$ & $2916(31)$ & $49(33)$ & 0.66 & $47(37)$ & 0.07 \\
\hline Severe TBI - AIS Head $\geq 3, n(\%)$ & $4233(45)$ & $65(43)$ & 0.12 & $79(53)$ & 0.51 \\
\hline \multicolumn{6}{|l|}{$\mathrm{BAC}, n(\%)$} \\
\hline Tested & $4397(46)$ & $65(43)$ & 0.46 & $82(55)$ & 0.043 \\
\hline Positive ( $\geq 2 \mathrm{mmol} / \mathrm{L}$ ) & $2010(21)$ & $38(25)$ & 0.041 & $45(30)$ & 0.10 \\
\hline \multicolumn{6}{|l|}{ Toxicology screen, $n(\%)$} \\
\hline Tested & $1823(19)$ & $14(9)$ & 0.002 & $20(13)$ & 0.07 \\
\hline Positive & $668(7)$ & $6(4)$ & 0.63 & $12(8)$ & 0.03 \\
\hline \multicolumn{6}{|l|}{ Outcomes } \\
\hline In-hospital LOS, mean \pm SD & $16 \pm 35$ & $14 \pm 22$ & 0.49 & $26 \pm 48$ & 0.003 \\
\hline ICU LOS, mean \pm SD & $4 \pm 11$ & $3 \pm 4$ & 0.16 & $5 \pm 9$ & 0.73 \\
\hline IMCU LOS, mean \pm SD & $2 \pm 4$ & $2 \pm 4$ & 1.00 & $3 \pm 4$ & 0.85 \\
\hline Complications, yes, $n(\%)$ & $2464(26)$ & $43(29)$ & 0.46 & 49 (33) & 0.06 \\
\hline Mortality, $n(\%)$ & $2955(31)$ & $\mathrm{n} / \mathrm{a}$ & $\mathrm{n} / \mathrm{a}$ & $46(31)$ & 0.89 \\
\hline $\begin{array}{l}\text { AIS = Abbreviated Injury Scale; BAC = blood alc } \\
\text { applicable; } \mathrm{SD}=\text { standard deviation; } \mathrm{TBI}=\text { traum } \\
{ }^{*} \text { Missing values: Age }(n=157), \mathrm{ISS}(n=164) \text {, } A \\
\text { 'T-test or chi square analysis comparing non-re }\end{array}$ & $\begin{array}{l}\text { ration; ICU = Intensi } \\
\text { ury; TTA = Trauma TE } \\
\text { re }(n=4391) \\
\text { initial or recurrent in }\end{array}$ & $\begin{array}{l}\text { ISS }=\text { Injury Se } \\
\text { n. } \\
\text { ists. }\end{array}$ & $\mathrm{ICU}=1$ & Care Unit; LOS = leng & \\
\hline
\end{tabular}

were more likely to be male and have a lower Injury Severity Score on emergency department (ED) arrival. Falls, motor vehicle collisions, and gunshots/violence were the most common injury causes (Supplementary Figure 1). More non-recidivists were injured in motor vehicle collisions, as compared with the index injury of the recidivists ( $25 \%$ v. $18 \%$, respectively; $p=0.047$ ), and more recidivists were injured by gunshots/violence (index injury), as compared with non-recidivists $(15 \%$ v. $9 \%$, respectively; $p=$ 0.014). Among recidivists, alcohol testing was performed in $43 \%(65 / 150)$ at the initial injury, with $58 \%(38 / 65)$ being alcohol positive. Alcohol testing rates increased over the study period, especially in patients with a trauma team activation (Supplementary Figure 2). This increase can be attributed to strong leadership by the provincial trauma program, forcing a shift in culture toward routine testing for alcohol.

Mortality was $31 \%$ for both recidivists and nonrecidivists. Recidivists had a longer in-hospital length of stay on recurrent injury ( $26 \pm 48$ days v. $16 \pm 35$ days, respectively). There were no differences in the length of stay in the ICU or intermediate care unit. Multivariate logistic regression models were created to assess factors associated with trauma recidivism and mortality (Supplementary Table 1). After adjusting for potential confounding factors, the likelihood of mortality was over three times greater for recidivists, as compared with nonrecidivists (odds ratio [OR] 3.67, 95\% CI 2.06-6.54). Recidivism was more likely in younger patients (OR $0.98,95 \%$ CI $0.97-1.00$ ) and patients for whom the trauma team was activated (OR 0.59, 95\% CI 0.34-0.96).

\section{DISCUSSION}

This is the first Canadian study of major trauma recidivism on a provincial level. The $2 \%$ rate in Nova Scotia is greater than the $0.38 \%$ rate in Toronto. ${ }^{5}$ We collected data from a provincial trauma registry; Caufeild et al. used registry data from two trauma referral centres (neither captured deaths at the scene or pre-hospital). If traumas of lesser severity are included, recidivism rates are 
considerably higher; a study from Sweden reported a $36 \%$ rate of recurrent moderate/severe injuries. ${ }^{10}$

In addition to the negative effects of recidivism on the patient and their loved ones, recidivism is a significant burden on the health care system. ${ }^{11,12}$ Hospitals and trauma centres are often the initial point of contact for patients dealing with violence or substance abuse; screening and brief intervention for these patients can reduce injury recurrence. ${ }^{13,14} \mathrm{~A}$ brief intervention for alcohol and illicit drug use reduced the incidence of trauma recidivism by $52 \% .{ }^{15}$ In our study, alcohol screening rates varied greatly, and a toxicology screening was performed infrequently; thus, our findings related to substance use must be interpreted with caution. With Canada set to legalize marijuana in 2018 , future investigations are planned to determine the impact of legalization on trauma recidivism. There may be a need to revisit and expand mandatory testing in the ED to include cannabis and alcohol in all trauma team activations.

This study was subject to inherent limitations of research on an existing dataset. Although data were collected from a robust provincial trauma registry, some variables had missing values. The registry does not capture socioeconomic status, ethnicity, history of criminal activity, or psychiatric illness. Furthermore, the registry is limited to major traumas, so we cannot account for any minor or moderate traumas that may have occurred. We may have underestimated the true rate of major trauma recidivism, as some patients grouped as nonrecidivists could have incurred another major trauma outside the province or beyond the study period. While alcohol status was categorized as positive or negative, our $2 \mathrm{mmol} / \mathrm{L}$ cut point is considerably lower than the forensic/legal limit of $17 \mathrm{mmol} / \mathrm{L}$. Further research is warranted to examine whether the degree of intoxication has an impact on major trauma recidivism.

\section{CONCLUSION}

In this provincial study of major trauma recidivism, $2 \%$ of patients were recidivists, but their likelihood of mortality was over three times greater, as compared with non-recidivists after adjusting for potential confounders. Screening and brief intervention may help to reduce recidivism rates.
Supplementary material: The supplementary material for this article can be found at https://doi.org/10.1017/cem.2018.496.

Acknowledgements: The data used in this research were made available by Trauma Nova Scotia at the Nova Scotia Department of Health and Wellness. Any opinions expressed by the authors do not necessarily reflect the opinion of the Nova Scotia Department of Health and Wellness or Trauma Nova Scotia. This work was supported by a Clinician Scientist Award from the Faculty of Medicine, Dalhousie University, Halifax, NS, Canada.

Competing interests: None declared.

\section{REFERENCES}

1. Reiner DS, Pastena JA, Swan KG, Lindenthal JJ, Tischler CD. Trauma recidivism. Am Surg 1990;56(9):556-60.

2. Kaufmann CR, Branas CC, Brawley ML. A population-based study of trauma recidivism. 7 Trauma 1998;45(2):325-32.

3. Allan BJ, Davis JS, Pandya RK, et al. Exploring trauma recidivism in an elderly cohort. 7 Surg Res 2013;184(1):582-5.

4. Sims DW, Bivins BA, Obeid FN, et al. Urban trauma: a chronic recurrent disease. 7 Trauma 1989;29(7):940-7.

5. Caufeild J, Singhal A, Moulton R, et al. Trauma recidivism in a large urban Canadian population. 7 Trauma 2004;57(4):872-6.

6. Strong BL, Greene CR, Smith GS. Trauma recidivism predicts long-term mortality: missed opportunities for prevention (retrospective cohort study). Ann Surg 2017;265(5):847-53.

7. Brooke BS, Efron DT, Chang DC, Haut ER, Cornwell 3rd EE. Patterns and outcomes among penetrating trauma recidivists: it only gets worse. 7 Trauma 2006;61(1):16-20.

8. Dixon SD, Como JJ, Banerjee A, Claridge JA. Trauma recidivists: surprisingly better outcomes than initially injured trauma patients. Am 7 Surg 2014;207(3):427-31.

9. IBM Corp. Released 2015. IBM SPSS Statistics for Windows, Version 23.0. Armonk, NY: IBM Corp.

10. Röding F, Lindkvist $M$, Bergström U, Svensson O, Lysholm J. Trauma recidivism at an emergency department of a Swedish medical center. Inj Epidemiol 2016;3(1):22.

11. Hayman AV, Crandall ML. Deadly partners: interdependence of alcohol and trauma in the clinical setting. Int 7 Environ Res Public Health 2009;6:3097-104.

12. Maier RV. Ethanol abuse and the trauma patient. Surg Infect (Larchmt) 2001;2(2):133-44.

13. Gentilello LM, Rivara FP, Donovan DM, et al. Alcohol interventions in a trauma center as a means of reducing the risk of injury recurrence. Ann Surg 1999;230(4):473-83.

14. Aboutanos MB, Jordan A, Cohen R, et al. Brief violence interventions with community case management services are effective for high-risk trauma patients. 7 Trauma 2011;71 (1):228-37.

15. Cordovilla-Guardia S, Fernández-Mondéjar E, VilarLópez R, et al. Effect of a brief intervention for alcohol and illicit drug use on trauma recidivism in a cohort of trauma patients. PLoS One 2017;12(8):e0182441. 